УАК 316.334 .2

ББК 60.561 .2

DOI 10.22394/1682-2358-2018-4-39-45

M.V. Sokolova, Candidate of Sciences (History), Docent of the Social and Disciplines and Humanities Department, Vladimir Branch of the Russian Presidential Academy of National Economy and Public Administration

\section{SOCIAL AND LABOR MOBILITY DYNAMICS OF VLADIMIR REGION POPULATION FROM 2005 TO 2017 (Based on Sociological Survey)}

Based on the data of sociological survey the variation of social and labor mobility of Vladimir region population from 2005 to 2017 is considered. The effect of gender, age, education level and settlement type on the population economic activity is analyzed. It is determined that among the reasons for changing jobs negative factors, such as closure of enterprises, staff reductions, and drop in wages, prevail.

Key words and word-combinations: social and labor mobility, unemployment, labor market.
М.В. Соколоља, кандидат исторических наук, дочент кафедри соииально-гуманитарньхх дисииплин Владимирского филиала Российской академии народного хозяйства и государственной службы при Президенте РФ (email: Rags33marina@ yandex.ru)

\section{АИНАМИКА СОЦИААЬНО-ТРУАОВОЙ МОБИАЬНОСТИ НАСЕ АЕНИЯ ВАААИМИРСКОЙ ОБААСТИ В ПЕРИОА С 2005 ПО 2017 ГОА (на основе данных соџиоло- гического опроса) ${ }^{*}$}

Аннотация. На основе данных социологического опроса рассматривается изменение социально-трудовой мобильности населения региона в период с 2005 по 2017 г. Выявляется зависимость экономической активности жителей региона от пола, возраста, уровня образования, а также места жительства. Определяется, что среди причин смены работы доминируют негативные факторы: закрытие предприятий, сокращение штатных единиц, падение уровня заработной платы.

Ключевые слова и словосочетания: социальнотрудовая мобильность, безработица, рынок труда.

Cost оциально-трудовая мобильность населения Российской Федерации в последние пятнадцать мет была подвержена значительным изменениям. Периоды стабильного

* Публикация подготовлена при финансовой поддержке РФФИ. Проект №17-13-33009 «Соџиокультурный потенџиал Владимирской области: Аинамика модернизационных процессов». 
соџиально-экономического развития сменялись кризисами, приводившими к массовым сокращениям и падению реальных Аоходов населения. Поиск новой работы или смена профессии в создавшейся ситуации становились вынужАенной мерой. Аругой не менее важной проблемой стало усиление разрыва межАу профессионацьной структурой населения, выходящего на рынок труда, и потребностями работодателей. Постепенно увеличивалось влияние социально-демографического и территориального факторов на возможность профессиональной реализации человека.

Обобщение специальных знаний позволицо выявить основные тенденции в сфере трудовой мобильности населения современного российского общества, в частности, отмечается частая смена не только места работы, но и профессии. В соответствии с важнейшими положениями теории трудовой мобимьности В.С. Молодецкая доказывает ее зависимость от соџиальных изменений [1, c. 110]. Существуют определенные соџиально-демографические особенности, в результате которых наиболее уязвимыми группами на рынке труда оказываются инвациды, пожилые мюди, жкенщины, выпускники школ, вузов и техникумов. ОАной из острейших проблем является реализация на рынке труда молодого поколения [2, с. 69; 3, с. 21]. Основные сложности, связанные со стартом профессионацьной деятельности, вкцючают отсутствие опыта, неумение организовать рабочий процесс, что снижает конкурентоспособность выпускников учебных заведений на рынке труда. В результате этих изменений численность безработных среди молодежи увеличивается. Реализация трудовой мобильности молодого поколения превращается в нелегкую проблему во множестве стран [4] .

Рост уровня безработиџы, снижение реальных доходов населения, повышение напряженности на рынке труда региона приводят к изменению социально-трудовых отношений, при которых экономически активное насецение становится более уязвимым. Ряд исследователей обращает внимание на формирование в ходе этих процессов неустойчивой занятости населения [5]. А.В. Растегаева, анацизируя негативные послеАствия прекаризации, подчеркивает, что они приводят к потере статусно-профессионацьных позиџий, разрушению устоявшейся системы соџиальной защиты работников и нарастанию проџессов Аекомективизаџии в соџиацьной структуре [7, с. 84, 88]. Миграционные передвижения населения, с одной стороны, способствуют более успешной реализации социально-трудовых функций, с Аругой - приводят к напряженности на рынке труда принимающей территории [8].

Характерной особенностью пограничных с Москвой и Московской областью территорий является значительный отток жителей в поисках более высокого уровня оплаты труда, что касается и Владимирской области. В 2018 г. на Аанной территории проводился соџиологический опрос с целью выявления особенностей соџиально-трудовой мобильности населения. В опросе приняли участие 807 респондентов, жкители региона разного пола и возраста, проживающие в разных муниципальных образованиях, имеющие размичный уровень образования. Выборка представцена достаточно репрезентативно. 
Установлено, что за последние 10-15 цет в результате соџиально-экономических колебаний в развитии регионов у значительной части жителей ВАадимирской области произошло изменение трудовой ориентации и трудовой деятельности. С 2005 г. только каждый третий респондент смог сохранить свою работу в той же организации и по той же специальности (35\%). Почти каждый второй житель Владимирской области (44,5\% ответивших) был вынужден сменить в последние двенадџать мет место трудоустройства. Внутренняя структура Аанной соџиальной группы связана с доминированием части жителей, сменивших и работу, и спещиальность (табц. 1).

Что изменилось

Таблища 1

в вашем трудовом положении с 2005 г.?

\begin{tabular}{l|c}
\hline \multicolumn{1}{c|}{ Вопросы } & Ответы, \% \\
\hline Вы работаете по той же специальности и в той же организации, что и в & 35,0 \\
2005 г. & 17,4 \\
Вы работаете по той же специальности, но перешли в другую организацию & 27,1 \\
Вы сменили и специальность, и организацию & 13,6 \\
Вы сейчас не работаете & 6,9 \\
Отказ от ответа & 100,0 \\
Итого &
\end{tabular}

В табц. 2 представлены половозрастные особенности изменения трудовой реализации насемения в периоА с 2005 по 2017 г. Мужчинам, как правиАо, удавалось сохранить и специальность, и место работы. Женщины чаще вынуждены были менять организацию трудоустройства, а также осваивать новую специальность. Наибольшая стабильность по сохранению места работы характерна для возрастной группы 45-54 мет - миц, уже занявших определенную профессиональную нишу и имевших больше возможностей Аля Аальнейшей трудовой реализаџии по собственной спещиальности и в той же организаџии. Отсутствие высоких показателей стабильности трудовой реализации в более старшем поколении связано с выходом части этой группы на пенсию. В предшествующее десятицетие жители ВАадимирской области, сохранившие соџиально-трудовую мобильность в возрасте старше 55 мет, меняли место работы по своей специальности почти так же часто, как и молодежь. Более неустойчиво выглядит возрастная группа 35-44 мет, в 2005 г. основная часть этой группы была в возрасте до 30 мет. В настоящее время значительное большее число ее представителей, чем кищ в возрасте 45-54 цет, не имеют постоянной работы. Рассмотрение изменений в трудовой мобильности жителей региона моложе 35 мет не представляется возможным, так как подавцяющая часть из них в 2005 г. еще не приступама к реализации трудовой функции. 
Таблииа 2

Изменения в трудовом положении с 2005 по 2017 г.: половозрастные особенности (\% от числа ответивших)

\begin{tabular}{l|c|c|c|c|c}
\hline \multicolumn{1}{c|}{ Вопросы } & Мужчины & Женщины & $\begin{array}{c}35-44 \\
\text { года }\end{array}$ & $\begin{array}{c}45-54 \\
\text { года }\end{array}$ & $\begin{array}{c}55 \text { лет } \\
\text { и старше }\end{array}$ \\
\hline $\begin{array}{l}\text { Вы работаете по той же } \\
\text { специальности и в той же } \\
\text { организации, что и в 2005 г. }\end{array}$ & 42,1 & 30,4 & 39,4 & 47,5 & 29,6 \\
$\begin{array}{l}\text { Вы работаете по той же } \\
\text { специальности, но перешли } \\
\text { в другую организацию }\end{array}$ & 14,3 & 19,4 & 19,3 & 17,5 & 16,9 \\
Вы сменили и специальность, & & & & & \\
и организацию & 23,8 & 29,3 & 27,5 & 31,3 & 18,3 \\
Вы сейчас не работаете & 12,7 & 14,1 & 11,0 & 3,8 & 32,4 \\
Отказ от ответа & 7,1 & 6,8 & 2,8 & 0,0 & 2,8
\end{tabular}

Жители малых и средних городов ВАадимирской области чаще Аругих в рассматриваемый период сохраняли работу в той же организации и по той же спеџиальности. Значительно чаще вынуждены были менять и место работы, и профессию сельские жители. Следует отметить, что в регионе практически не существует разниџы в динамике трудовой реализаџии населения областного центра и других городов. Связано это прежде всего с идентичной структурой и однотипными проблемами в данной сфере.

Владимирская область - достаточно спещифическая территория по уровню образования населения в Центральном федеральном округе. В советское время существовала разветвленная система начального и среднего специального образования, в результате в структуре населения, особенно среди старших возрастных групп, доминируют именно эти представители. Подавляющая часть из них работала на промышленных предприятиях. В проџессе закрытия крупных преАприятий эта часть населения оказалась наиболее уязвимой на рынке труда региона.

Несмотря на существуюшее мнение о «перепроизводстве» выпускников высших учебных заведений, именно эта группа наиболее востребована на рынке труда Вцадимирской обцасти. В перерасчете на численность житемей их меньше, чем в большинстве Аругих субъектов Центральной России. Соответственно, и конкуренџия внутри этих профессиональных групп значительно ниже. Аипломированные бакалавры, специалисты, магистры и выпускники аспирантуры имели больше возможности в последние 10-15 мет Аля сохранения своего места работы. Среди них процент безработных самый незначительный. Выпускники школ, не продолжившие свое обучение, чаще Аругих оказываются не в состоянии найти работу, чем объясняется Аостаточно масштабное увеличение количества студентов высших учебных 
заведений в данный период. Система высшего образования постепенно становится неотъемлемым элементом соџиацизаџии вслеАствие того, что рынок труаа не в состоянии принять большое количество выпускников школ. С 2005 по 2017 г. среАи молодежи значительно увеличилось число представителей с высшим образованием (табл. 3). Наиболее уверенно на рынке труда себя ощущают работники здравоохранения, так как Вмадимирский регион не имеет самодостаточности в подготовке компетентных специацистов.

Таблица 3

Аинамика соџиально-трудовой мобимьности населения в зависимости от типа поселения и уровня образования, \%

\begin{tabular}{|c|c|c|c|c|c|c|c|}
\hline \multirow[b]{2}{*}{ Вопросы } & \multicolumn{3}{|c|}{ Место жительства } & \multicolumn{4}{|c|}{ Уровень образования } \\
\hline & 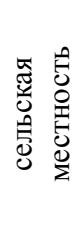 & 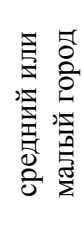 & 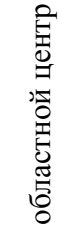 & 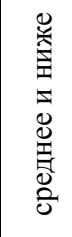 & 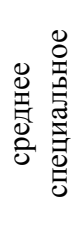 & 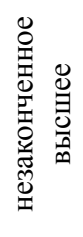 & 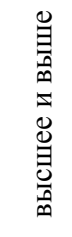 \\
\hline $\begin{array}{l}\text { Вы работаете по той же } \\
\text { специальности в той же } \\
\text { организации, что и в } 2005 \text { г. }\end{array}$ & 31,1 & 37,8 & 33,1 & 21,4 & 32,5 & 18,2 & 44,9 \\
\hline $\begin{array}{l}\text { Вы работаете по той же } \\
\text { специальности, но перешли } \\
\text { в другую организацию }\end{array}$ & 13,3 & 18,2 & 18,2 & 14,3 & 17,1 & 13,6 & 18,9 \\
\hline $\begin{array}{l}\text { Вы сменили и специальность, } \\
\text { и организацию }\end{array}$ & 35,6 & 25,2 & 25,6 & 26,2 & 30,8 & 27,3 & 23,6 \\
\hline Вы сейчас не работаете & 13,3 & 14,7 & 12,4 & 26,2 & 13,7 & 18,2 & 9,4 \\
\hline Отказ от ответа & 6,7 & 4,2 & 10,7 & 11,9 & 6,0 & 22,7 & 3,1 \\
\hline
\end{tabular}

Жители ВАадимирской обцасти, сумевшие сохранить свою работу после мирового экономического кризиса 2008 г. и 2014-2015 гг., руководствовамись такими критериями, как «некуда уходить», «другой работы не было» (19,7\%), «привык к своей работе и коммективу» (20,1\%). Существенным оказался и такой параметр, как «интересная работа» (15,7\% ответивших). Высокий уровень оплаты труда стал причиной Аля сохранения имеющегося варианта трудоустройства Амя 12,6\% респондентов. Практически каждый десятый сохранял свою работу потому, что она почетная, уважаемая, престижная или приносящая пользу обшеству (9,8\%). Не задумываются наА сменой профессии и места трудоустройства, поскольку их работа благотворно влияет на их соџиальное положение, 4,7\% ответивших (табл. 4). 
Почему сохраними работу?

Таблииа 4

\begin{tabular}{l|c}
\hline \multicolumn{1}{c|}{ Причина сохранения работы } & Ответы, \% \\
\hline Работа интересная & 15,7 \\
Работа почетная, уважаемая, престижная, приносит пользу людям & 9,8 \\
Работа хорошо оплачивается & 12,6 \\
Мне некуда уходить, другой работы у меня не было & 19,7 \\
Я привык к своей работе, к коллективу & 20,1 \\
Мне так спокойнее & 4,7 \\
Другое & 2,4 \\
Не знаю & 2,0 \\
Отказ от ответа & 13,0
\end{tabular}

Смена работы респондентами обусловлена вынужденными причинами или появлением в профессиональной деятельности новых возможностей. Негативные факторы способствовали смене работы почти у $40 \%$ респондентов: плохо оплачивалась $(17,7 \%)$; были сокращения; предприятие закрыто $(17,3 \%)$; работа по имеющейся спещиальности стала не нужна $(3,6 \%)$; предылущая работа не пользовалась уважением (2,0\%). Около $30 \%$ участников опроса сменили работу по причине появившихся новых возможностей соџиально-трудовой реализаџии: более интересная работа $(15,3 \%)$; больше возможностей проявить себя $(4,8 \%)$; профессиональная реализация благодаря получению образования $(7,2 \%)$; повышение по служебной кестнице $(1,6 \%)$ (табц. 5).

Почему сменили работу?

Таблица 5

\begin{tabular}{l|c}
\hline \multicolumn{1}{c|}{ Причины смены работы } & Ответы, \% \\
\hline Появилась возможность более интересной работы & 15,3 \\
Работа не пользовалась уважением & 2,0 \\
Были сокращения, предприятие было закрыто & 17,3 \\
Работа по моей специальности сейчас не нужна & 3,6 \\
Работа плохо оплачивалась & 17,7 \\
На новой работе я имею больше возможностей проявить себя & 4,8 \\
Получил образование / дополнительное образование & 7,2 \\
Сменил место жительства, переехал & 4,8 \\
Продвинулся по служебной лестнице & 1,6 \\
Не знаю & 4,8 \\
Отказ от ответа & 20,9
\end{tabular}

44 Bulletin of the Volga Region Institute of Administration • 2018. Vol. 18. № 4 
Желание повысить уровень своей профессиональной реализации приводит не только к необходимости получения нового образования, поиску другой организации трудоустройства, но и иногда смены места жительства. Аیя 4,8\% житемей ВАадимирской области переезА на Аругую территорию стал в это

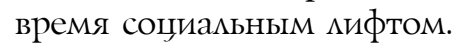

Полученные в результате исследования данные свидетельствуют о достаточно активном проџессе смены места трудоустройства населением Вцадимирской обмасти в период с 2005 по 2017 г. Значительная часть жителей региона вынуждена была осваивать новую специальность и искать работу в результате сокращений, закрытия преАприятий или снижения уровня заработной платы. Воздействие негативных факторов на общество становится опредемяющим при смене места трудоустройства гражАанами; изменение соџиально-трудовой мобильности Аюдей как смедствие профессионального роста происходит значительно реже.

Половозрастные особенности свидетельствуют о более стабильном положении на рынке труда мужчин и в целом жителей региона в возрасте 45-54 мет. Самыми незащищенными от влияния соџиально-экономических комебаний оказались жители сельской местности. Наличие высшего и послевузовского образования положительно влияло на соџиально-трудовую мобильность населения. Более стабильное положение на рынке труда выпускников вузов является результатом достаточно специфического распределения насемения региона по уровню образования. Такое соотношение нехарактерно Амя других субъектов Центрального федерального округа.

В большинстве случаев жители не меняют своего места работы в результате привыкания к трудовому комлективу или отсутствия возможности найти более интересный и высокооплачиваемый вариант трудоустройства. Положкительный эффект внутри поколенной соџиально-трудовой мобильности достигается через получение нового образования, переезАа на Аругую территорию или в результате появления дополнительных возможностей Аля профессиональной реализаџии.

\section{Библиографический список}

1. Молодецкая В.С. Трудовая мобильность: трансформация теоретических подходов в условиях общественных изменений // Вестник Поволжского института управления. 2018. Т. 18, № 2. C. 104-111.

2. Гречихин В.Г. Безработная молодежь на современном российском и мировом рынке труда // Общество: социология, психология, педагогика. 2018. № 2. С. 68-71.

3. Кильдютева O.A. Безработица в молодежной среде российского общества: особенности проблемы и пути борьбы с ней на современном этапе // Общество: социология, психология, педагогика. 2017. № 1. С. 20-22.

4. Maguire S. [et al.]. Youth Unemployment // Intereconomics. 2013. Vol. 48, № 4. P. 196-235.

5. Лобова C.B. Прекаризированная (неустойчивая) занятость в структуре рынка труда региона // Социодинамика. 2017. № 5. С. 83-97.

6. Флеров O.B. Мотивация, лояльность и корпоративная культура в условиях безработицы и сокращений в эпоху социально-экономической неопределенности // Политика и общество. 2015. № 7. C. 919-929.

7. Растегаева A.B. Прекаризация на современном рынке труда: основные признаки и причины распространения // Вестник Поволжского института управления. 2018. Т. 18, № 3. С. 82-88.

8. Лакомова А.А., Хусяинов Т.М. Влияние миграционных процессов на региональный рынок труда (на примере Нижегородской области) // Политика и общество. 2015. № 8. С. 1070-1075. 